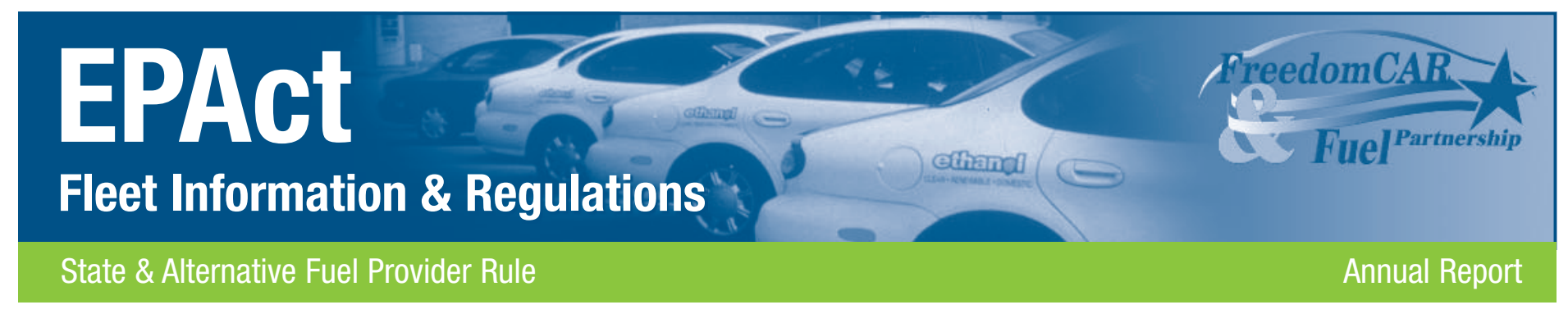

\title{
Activities and Accomplishments in MY 2005/FY 2006
}

In model year (MY) 2005, covered state and alternative fuel provider (S\&FP) fleets that report to the U.S. Department of Energy (DOE) complied with Energy Policy Act of 1992 (EPAct) fleet provisions (10 CFR Part 490) by:

- Acquiring more than 10,000 alternative fuel vehicles (AFVs).

- Earning nearly 2,400 biodiesel credits.

- Purchasing almost 1,100 AFV credits.

Results published in this report show that fleets continue to successfully meet their EPAct requirements by using alternative fuel technologies. DOE continues to see increases in biodiesel use and the number of new lightduty vehicles (LDVs) acquired, as fleets appear to be buying a higher proportion of new vehicles. Additionally, the use of credits increased, as did the number of ethanolcapable flexible fuel vehicles (FFVs) purchased. For MY 2005 reporting highlights, see Table 1.

\section{Status of Covered Fleets}

In MY 2005, all 316 entities* covered by the S\&FP rule reported to DOE. This outstanding level of compliance is credited to the many ways fleets are allowed to meet their requirements. These include acquiring light-duty AFVs, purchasing credits from other fleets, using banked credits, and using biodiesel.

\section{Vehicle Acquisitions}

AFV acquisition is the predominant method of compliance. Under S\&FP regulations, $75 \%$ of new covered LDVs acquired by state fleets must be AFVs, while $90 \%$ of

\footnotetext{
* Some entities represent one agency or business; others constitute fleet operations for an entire state.
}

\begin{tabular}{|l|c|}
\hline \multicolumn{2}{|c|}{ Table 1. MY 2005 Highlights } \\
\hline AFVs Purchased & 10,033 \\
\hline Banked Credits Used & 2,731 \\
\hline Credits Purchased & 1,053 \\
\hline Biodiesel Used & 3.4 million gallons (B100) \\
\hline Biodiesel Credits Awarded & 2,381 \\
\hline
\end{tabular}

LDVs acquired by alternative fuel providers must be AFVs. AFV acquisition requirements are determined by multiplying a fleet's number of newly acquired, nonexcluded LDVs by the applicable percentages. In MY 2005 , the number of covered LDV acquisitions was 16,674 , a $24 \%$ increase from the previous year. The actual number of AFV acquisitions required by the program was 12,318 .

To meet this requirement, covered fleets acquired 10,033 AFVs in MY 2005-also a 24\% increase from the previous year. With more than 9,100 vehicles acquired, state fleets purchased the vast majority of the AFVs reported in MY 2005. In fact, they acquired 2,500 more AFVs than the year before. This increase, however, is consistent with MY 2005's AFV requirement for state fleets, which was 2,474 higher than in MY 2004.

The MY 2005 requirement for fuel provider fleets was 3,649 AFVs, 140 shy of MY 2004's requirement of 3,789 vehicles. Almost one-third of this was met through the purchase of AFVs. As in previous years, fuel providers met their AFV requirement primarily through the use of banked credits and biodiesel. For AFV acquisitions by state and alternative fuel provider fleets, see Figure 1. For the breakdown on the types of AFVs purchased in MY 2005, see Table 2. 


\begin{tabular}{|l|c|}
\hline \multicolumn{2}{|c|}{ Table 2. AFVs Acquired in MY 2005 } \\
\hline Light-Duty Sedans & 5,269 \\
\hline Light-Duty Pickups & 2,132 \\
\hline Minivans & 1,438 \\
\hline Sport Utility Vehicles & 882 \\
\hline Full-Sized Vans & 55 \\
\hline Medium-Duty Trucks & 231 \\
\hline Heavy-Duty Trucks & 26 \\
\hline
\end{tabular}

Figure 1. Number of AFVs Acquired in MY 2005 (by Covered Fleets)

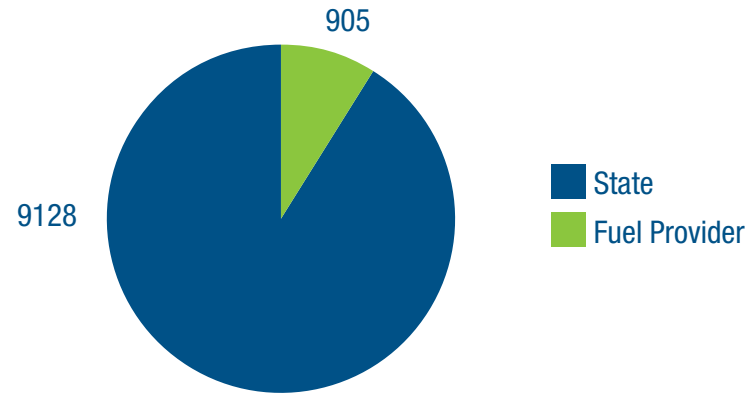

Figure 2. Credits Purchased Annually

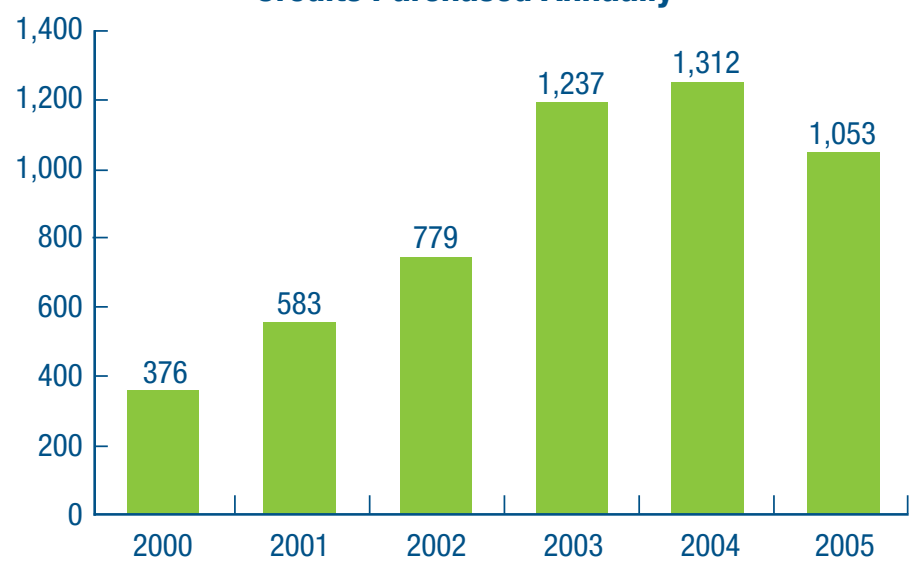

Figure 3. Annual Biodiesel Fuel Use

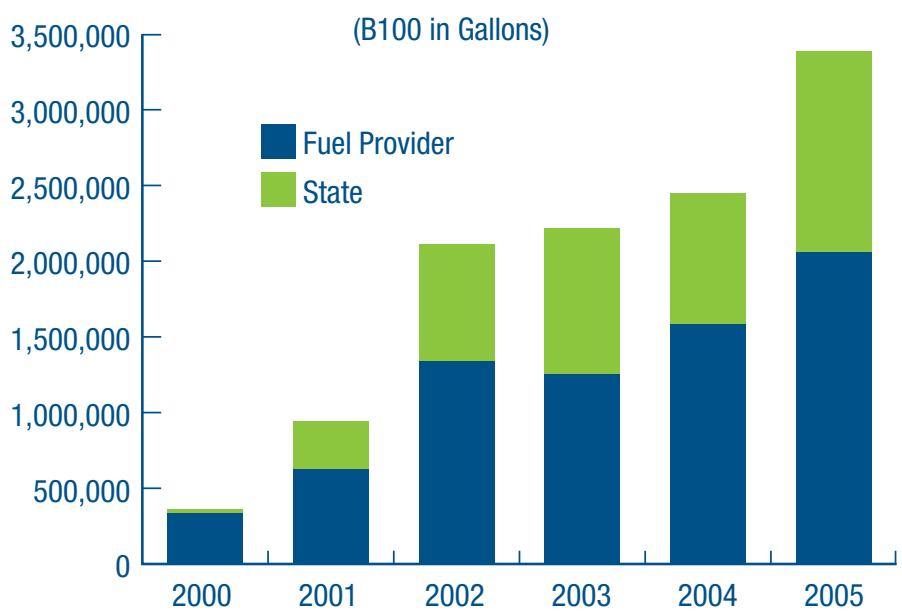
B100) in MY 2005, while 65 alternative fuel provider fleets used 2.1 million gallons of B100. Although Figure 3

\footnotetext{
* For more information on how biodiesel credits are calculated, download "Reporting Biodiesel Fuel Use Credits" from the EPAct website at www.eere.energy.gov/vehiclesandfuels/epact/pdfs/biodiesel_guidance.pdf.
} 


\section{Fleet Fuel Preferences}

In MY 2005, FFVs that run on E85 accounted for $91 \%$ of newly acquired AFVs. Vehicles powered by compressed natural gas (CNG) and liquefied natural gas came in second at $7 \%$, followed by liquefied petroleum gas (LPG) vehicles at $1 \%$. The previous year's AFV breakdown was $69 \%, 21 \%$, and $8 \%$ respectively. These percentages reflect a dramatic shift away from gaseous fuel vehicles to those that can run on E85. This is to be expected, however, since gaseous fuel vehicle offerings were limited in MY 2005.

Of the 9,107 FFVs acquired in MY 2005, 8,803 were purchased by states. Although EPAct does not require states to use alternative fuels in their AFVs, more and more fleets are using E85 in their FFVs. In fact, many are installing onsite fueling infrastructure in response to local mandates requiring them to use E85 and other alternative fuels in state vehicles. According to DOE's Alternative Fuels Data Center, the total number of E85 fueling sites in the United States doubled since MY 2005, bringing the total to 841 stations*.

FFV acquisitions by alternative fuel provider fleets also increased in MY 2005. These fleets purchased 304 FFVs, up from 240 in MY 2004. DOE expects this trend to continue due to limited AFV offerings by OEMs and an increasing number of E85 refueling stations.

${ }^{\star}$ As of September 2006.

Figure 4.

AFVs Acquired by Covered Fleets

$(10,030 \mathrm{AFV})$

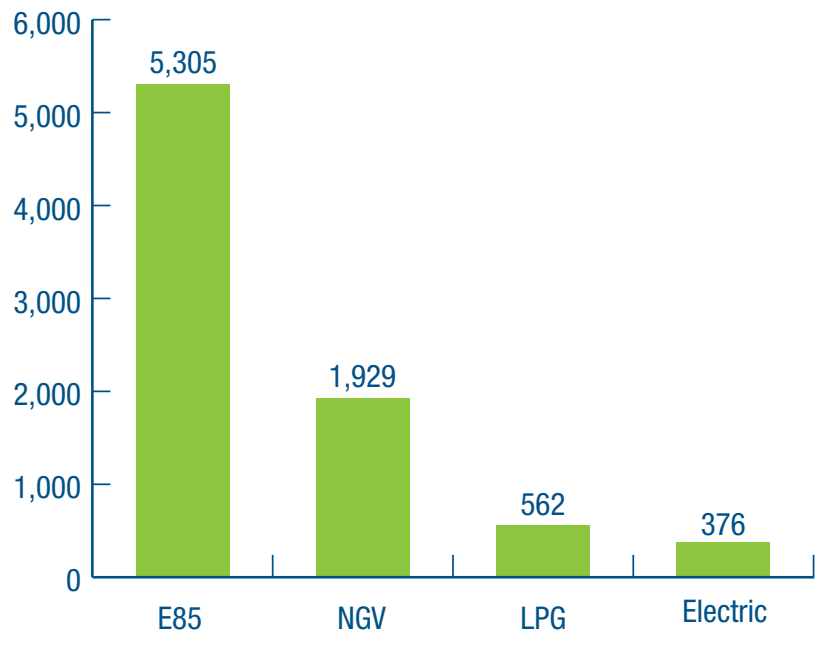

shows fuel providers to be the predominant users of biodiesel, state fleet use also continues to increase.

\section{Exemptions}

Overall, exemptions* in MY 2005 represented a small percentage of fleet activity. For the first time since 2001, however, exemptions granted to fleets increased. Forty fleets received 952 vehicle exemptions this year-a slight increase from the 806 granted in MY 2004.

\section{Program Activities and Accomplishments}

In fiscal year (FY) 2006, DOE continued to work with fleets to increase the number of AFVs acquired and to expand the use of alternative fuels. Efforts included stakeholder education, communication with covered fleets, and presentations at workshops and conferences.

\section{Stakeholder Education}

During FY 2006, DOE sent letters to determine whether all alternative fuel provider fleets covered under the Alternative Fuel Transportation Program (10 CFR Part 490) are complying and submitting annual reports. This effort consisted of sending letters to known covered fuel provider fleets to confirm their subsidiaries are included in their DOE annual reports. Letters were also developed for fleets with subsidiaries that currently do not report to DOE but may be covered.

Also in FY 2006, DOE worked with state entities, including universities, to identify other potentially covered fleets.

\section{Communications, Workshops, and Presentations}

In FY 2006, DOE also sent covered fleets announcements and reporting reminders. In addition, e-mails and letters were sent to covered fleets that failed to file timely reports. Fleets with credit deficiencies were also sent letters that summarized their compliance status and how to purchase credits or otherwise resolve deficiencies.

On June 23, 2006, DOE issued a Notice of Proposed Rulemaking for Alternative Compliance. The notice for this new program, which was outlined by EPAct 2005, proposes procedures for covered fleets to apply for waivers and pursue petroleum reduction in lieu of the current

* Exemptions are detailed in the addendum to "Documentation Requirements for Exemption Requests," which is available on the EPAct website at www.eere.energy.gov/vehiclesandfuels/epact/pdfs/ exemption_addendum2.pdf. 
AFV acquisition approach. DOE developed an electronic docket on the EPAct website that displays documentation related to the rulemaking. DOE also held a public hearing on July 12, 2006, that was attended by national trade groups representing fleets, utilities, and alternative fuel producers. The hearing transcript and oral comments are posted on the website, along with public written comments that were accepted through August 7, 2006. The docket, which is available at wwwl.eere.energy.gov/vehiclesandfuels/epact/statelafc_docket.html, also features Federal Register notices and other documents on alternative compliance.

DOE organized presentations at four state workshops in MY 2005. They included the North Carolina Workshop for state university fleet managers in Raleigh; the Texas Biodiesel/E85 Workshop in Austin; the Maryland Energy Administration Biodiesel Workshop in Beltsville; and the Virginia Biofuels Forum/Biodiesel Workshop in Arlington. DOE also made a presentation for covered fleets at Edison Electric Institute's annual workshop in Washington, D.C.

\section{What Is EPAct?}

The Energy Policy Act of 1992 (EPAct) was passed by Congress to reduce the nation's dependence on imported petroleum. Provisions of EPAct require certain fleets to purchase AFVs. DOE administers these requirements through its State \& Fuel Provider Rule, Federal Fleet Rule, and Alternative Fuel Designation Authority.

For more information, visit www.eere.energy.gov/vehiclesandfuels/ epact, or call the Regulatory Information Line at 202-586-9171.
Finally, DOE exhibited materials on state and fuel provider activities at the National Conference of State Fleet Administrators in Coeur d'Alene, Idaho; the National Biodiesel Board's Conference \& Expo in San Diego, California; and the Clean Cities Congress in Phoenix, Arizona.

\section{Future Activities}

Looking ahead, DOE will work toward issuing a final rulemaking on alternative compliance and will develop online guidance materials. Other activities for FY 2007 include a comprehensive instructional packet to inspire fleets to find and develop fueling infrastructure and fact sheets detailing the successful AFV programs of state and alternative fuel provider fleets.

In FY 2007, DOE will also work with state fleets to encourage increased ethanol use in mandated AFVs.

\section{Conclusion}

In MY 2005, covered fleets were successful in their efforts to comply with S\&FP requirements. As part of their compliance efforts, covered fleets acquired more than 10,000 AFVs and consumed more than 3 million gallons of biodiesel (B100). All fleets have reported, and the few fleets with deficiencies are resolving them. DOE has maintained its outreach efforts by communicating with a number of covered and potentially covered fleets, developing an online docket and holding a public hearing for the Alternative Compliance Notice of Proposed Rulemaking, and participating in regional and national workshops and events.

\footnotetext{
Sponsored by the U.S. Department of Energy

Energy Efficiency and Renewable Energy

FreedomCAR and Vehicle Technologies Program

For more information contact: EERE Information Center

1-877-EERE-INF (1-877-337-3463)

www.eere.energy.gov

A Strong Energy Portfolio for a Strong America

Energy efficiency and clean, renewable energy will mean a stronger economy, a cleaner environment, and greater energy independence for America. Working with a wide array of state, community, industry, and university partners, the U.S. Department of Energy's Office of Energy Efficiency and Renewable Energy invests in a diverse portfolio of energy technologies.

DOE/GO-102006-2355 • October 2006
}

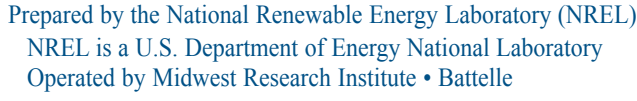

Neither the United States government nor any agency thereof, nor any of their employees, makes any warranty, express or implied, or assumes any legal liability or responsibility for the accuracy, completeness, or usefulness of any information, apparatus, product, or process disclosed, or represents that its use would not infringe privately owned rights. Reference herein to any specific commercial product, process, or service by trade name, trademark, manufacturer, or otherwise does not necessarily constitute or imply its endorsement, recommendation, or favoring by the United States government or any agency thereof. The views and opinions of authors expressed herein do not necessarily state or reflect those of the United States government or any agency thereof.

Printed with a renewable-source ink on paper containing at least $50 \%$ wastepaper, including $10 \%$ postconsumer waste 